\title{
Introduction: anti-entropy - the idea of progress
}

The struggle between optimism and pessimism is endemic to human thought, and its ebb and flow is naturally affected by the economic and social state we are in at particular times. (Bronk, Progress and The Invisible Hand) ${ }^{1}$

The idea of Progress has had a stormy journey through the ages. In fact, for most political philosophers, starting with Plato, the very opposite view prevailed. Human society, it is supposed, is in a perpetual process of decay from an earlier state of perfection. Similarly, in the Judeo-Christian tradition, man and woman were cast out of the Garden of Eden, thereafter, to suffer for their original sin. In every century harbingers of doom arose to point out the inevitable fall from grace, especially during times of great social and political dislocation. In the early centuries of the Christian Era the Church fathers stressed the fragility and futility of struggling to improve matters in this life. Given the disorder and dangers caused by the break-up of the Western Roman Empire, such a reading of everyday life was understandable, as was the injunction to prepare for the afterlife and look forward to the time when Christ returned to gather up his faithful flock. St. Augustine's City of God painted an optimistic picture of finally reaching this happy state - though he was vague as to when it would happen. Many believers are still waiting.

In the ancient world, both Plato and Aristotle were cognisant of the tendency of real polities to degrade. Both feared the eventual triumph of mob rule, the end game of classical democracy. The gloomy picture of the human condition began to be challenged during the Renaissance, though cautiously. Growing commercial wealth dominated by the Italian Mediterranean city states and the emerging cultural and scientific advances there and in Northern Europe suggested that human progress was at least possible, though not guaranteed. Machiavelli, straddling the old and new eras, was sceptical, and looked instead to circularity in history, stressing the twin roles of 'fortuna' and 'virtú', generally translated as fortune and strength. ${ }^{2}$ The normal course of history is charted

1 In addition to Bronk's book, classic reviews of the idea of progress in history are presented by Nisbet (2009) and Bury (1920).

2 Virtú is notoriously difficult to translate. It has a complex range of meanings. It is often mistakenly given the sense of 'virtue' in English; for example, Collier (2019). 
by repeated cycles of improvement and decline. Thus, in his history of the Florentine republic he argued:

In their normal variations, countries go from order to disorder and then from disorder back to order, because - since Nature does not allow worldly things to remain fixed - when they come to their utmost perfection and have no other possibility of rising, they must go down. Likewise, when they have gone down and through their defects have reached the lowest depths, they necessarily rise since they cannot go lower. So always from the good they go down to bad and from bad rise to the good. (quoted in Nisbet, 2009, p. 107) ${ }^{3}$

For Machiavelli virtú trumps fortune. The latter is capricious and difficult to predict. But the strong man can, if shrewdly waiting for fortune's opportunities, impress his rule upon his society. This view is most clearly put in his most famous book, The Prince, where he gives rulers a masterclass in how to establish and consolidate their authority.

I conclude. Therefore, that as fortune is changeable whereas men are obstinate in their ways, men prosper as long as fortune and policy are in accord, and when they clash, they fail. I hold strongly to this: it is better to be impetuous than circumspect; because fortune is a woman and if she is to be submissive it is necessary to beat and coerce her. Experience shows that she is often subdued by men who do this than by men who act coldly. Always being a woman, she favours young men, because they are less circumspect and more ardent, they command with greater audacity. (Machiavelli, 2006/1513, pp. 123-4)

Princes and dictators have ever since heeded the injunction to command with audacity. So too have women in the few historical instances that fortune gave them the chance. Elizabeth I of England and Catherine the Great of Russia can hardly be accused of excessive circumspection. Nevertheless, for Machiavelli, nothing lasts. The great republics and principalities rose and fell with fortuna working behind and virtú in front of the scenes to eventually bring down the Roman republic and empire, just as it did the Florentine republic and the competing princes of the Italian peninsula. In Machiavelli's world, war and plague kept populations oscillating and living standards stagnant. In a zero-sum world, the idea of permanent progress seemed far-fetched at best

According to the entry in Wikipedia, 'Machiavelli suggests a different set of virtues than Aristotle and Thomas Aquinas apparently with less focus on beneficence and concord, and with more focus on courage. According to Machiavelli, virtù includes pride, bravery, skill, forcefulness, and an amount of ruthlessness coupled with the willingness to do evil when necessary' (https://en.wikipedia.org/wiki/Virtù).

3 Bronk (1999, p. 44) comments: 'not surprisingly, therefore, many Renaissance thinkers emphasised a cyclical view of history. So, Machiavelli saw history as subject to "ricorsi" - cycles from order to disorder and back to order.' 
and sacrilegious at worst. 'Revolution', in its original astronomical context, meant coming back to where you started. It would be three hundred years before the idea of a sharp break and forward leap would become associated with revolution as the midwife of social progress.

But at the time Machiavelli was admiring the triumph of Virtú manifested by Cesare Borgia great changes were afoot. Discovery of the New World opened unheard of riches and trading opportunities. The rumblings of Reformation challenged the control of the Church over both spiritual and temporal matters, unleashing a scramble for political power in the previously sleepy region of North West Europe. Finally, from the late sixteenth century onward, advances in science, religion and philosophy presented new mental models for viewing and acting in the world and offered the prospect of increasing population and opulence.

Late-eighteenth-century political economists looked to the magic of the market to free humanity from the historical chains of material scarcity, political repression and cultural stagnation. Adam Smith's canonical book, An Inquiry into the Nature and Causes of the Wealth of Nations, laid out a powerful argument for encouraging innovation and growth, though cognisant of the many institutional and political barriers to his preferred future. Like the Bible, The Wealth of Nations is a sprawling narrative, full of apparent contradictions and capable of providing support for varying and opposing interpretations. Its very wide canvas - dissecting historical development over millennia, the determination of prices, wages, interest and rent, international trade, the dynamics of economic growth, the inadequacies of prevailing government policy and the role and financing of government - positively invites arguments over meaning and emphasis. In particular, the rich broth of ideas encourages selective quotation in support of fixed positions and entrenched vested interests (material and ideological). ${ }^{4}$

Smith's generally upbeat hymn to human progress found ample interest and amplification in revolutionary France. In particular, the philosopher and mathematician Marie Jean Antoine Nicolas, Marquis de Condorcet, saw and celebrated emerging free market capitalism breaking down the age-old structures of privilege and superstition. He optimistically presented an outline of an inevitable historical march of progress in ten easy stages. His Sketch for a Historical Picture of the Progress of the Human Mind painted a picture of a steady progress in the natural and social sciences, including political

4 See Norman (2018) for a detailed critique of the narrow reading of Smith's analysis of capitalism favoured by proponents of 'free markets'. Rothschild (2002) has also provided a nuanced historical view of the role of moral philosophy in Smith's broad-ranging economic analysis of early capitalism. 
economy, that would lead to an ever more just and peaceful world characterised by rational thinking, individual freedom, material wellbeing and moral compassion. Condorcet did not live to see his conjured future world, dying in prison during the dog days of the revolutionary terror, a somewhat ironic ending.

Subsequently, both Marx and Keynes argued that capitalism, as it had emerged in the West, was the dynamic vehicle by which permanent social progress could and would be achieved, though they had very different explanations for how this happy state of affairs would occur - and how it would end. For Marx, increasing material and cultural polarisation would create the material and political conditions for revolutionary change, ${ }^{5}$ leading to a society of cooperative producer-citizens. In his attempt to break away from the Young Hegelians, he argued that philosophers must understand the material world as it is and is becoming, through the cooperative production of material life. In his eleventh thesis on Feuerbach, he posed the challenge: 'Philosophers have hitherto only interpreted the world in various ways; the point is to change it.' Marx is here rescuing History from the (idealist) philosophers and returning it to the people, who together make it.

Here, the relative order of the history of ideas of the Hegelian history of thought, in which ideas encounter other ideas and of philosophers who learn from each other or struggle against each other, does not prevail. Instead a chaotic multiplicity dominates in which everything can seem important and common people are part of creating history ... At the same time, this kaleidoscopic multifarious history is a history of change - development, in fact - just as much as philosophy is. However multifarious and however mixed up with small coincidences it may be, at the same time it seems to display a pattern or an aim, even if it is difficult to substantiate its major features in the small details ... It is the history of the multiplicity that Marx wants to bring in focus. It is there that real change occurs, and it is also there that every person can appear as both marked by circumstances they cannot prevail over, and as active and creative. (Liedman, 2018, pp. 177-8)

Of course, Marx spent the rest of his life trying to explicate exactly how this process was unwinding in the capitalism of his day, by a prodigious critique of classical political economy.

Keynes relied on technological developments and the 'magic of compound interest', or the relatively peaceful spread of material plenty from the inno-

5 Marx, unlike contemporaries, saw the French revolution and those failed uprisings in 1848 as social revolutions enthroning the class rule of the emerging capitalist class, and thus as a progressive step on the road to the end of class division and rule itself. As such, he embraced a teleological conception of revolution rather than the "turn of the wheel, return to where you began' view that hung over from medieval times and was buttressed by the conservative reactions following 1780-93 and 1848-52. 
vations and capital accumulation of profit-grubbing capitalists, whose very success would eventually ('at least a hundred years' hence') cause them as a class to wither away once a high level of general affluence had been achieved. Keynes never considered the possibility that the dominant capitalist class might have an aversion to withering and might so arrange the institutions of economy and polity - Rawls's basic structure - as to perpetuate their dominance. However, he did place a qualification on the realisation of his possible progressive future:

The pace at which we can reach our destination of economic bliss will be governed by four things - our power to control population, our determination to avoid wars and civil dissentions, our willingness to entrust to science the direction of those matters which are the proper concern of science, and the rate of accumulation as fixed by the margin between our production and our consumption; of which the last will easily look after itself, given the first three. (Keynes, 1972/1931, p. 331)

In fact, the 90 years since this brave forecast was made has seen the first three conditions repeatedly breached and the fourth condition questioned radically by Keynes himself a bare half-dozen years after its statement. In The General Theory, Keynes (1973/1936) argued that, if left to themselves, capitalists would systematically underinvest, creating a growing gap between the potential productive capacity of the economy and its actual material output and income. Government, missing from the earlier picture, would need to close the gap through public investment. It becomes the government's role to ensure adequate total investment in the economy by way of ensuring that long-term interest rates remain low and through direct investment in socially beneficial uses like public housing, transport, education and health services; this, he mischievously terms 'the socialization of investment'. Judicious redistributive taxation can also increase aggregate consumption due to the higher marginal propensity to consume of lower income people, thereby reducing the weight cast on investors (public and private) to maintain maximum employment of resources and hence the speediest realisation of economic bliss.

A few years before he had worked out the bones of his general theory, Keynes had speculated on the 'economic possibilities for our grandchildren'. Like Marx he saw capitalism as an economic system that prioritised the production and accumulation of wealth. But unlike Marx (and like John Stuart Mill), he also looked to a future, some two generations on, when the fruits of wealth accumulation would ensure a more than comfortable material and spiritual existence for virtually all citizens fortunate enough to live in societies like his own. For the first 30 years after World War II, a period often referred to as 'the long post-war boom', Keynes's prophecy seemed to be bearing fruit, at least in the advanced Western nations, in part due to the widespread practice of 'Keynesian' policies, in part to the natural dynamic of capitalism reconstruct- 
ing the infrastructure of economies devastated by War. Living standards rose across most of the class structure. The extremes of social inequality softened as high employment and rising wages reduced income inequality before taxes and steeply progressive taxes on income and wealth further flattened the post-tax distribution, assisted by the growth of country-specific 'welfare states'. The picture was not so rosy in the periphery where centuries of colonial domination had impoverished the masses and eventually sparked nationalist revolutions.

But during the 1970s, the era that Keynes had pinpointed as the prospective economic nirvana, the economic miracle began to unwind. Machiavelli's cycle turned again, as unemployment rose along with inflation, something that Keynes would have understood but his self-professed followers didn't. The response across the Western world was an about face, as the older neoclassical theories and nostrums were dusted off and fed into policy. With hindsight, we now term this period the era of neoliberalism, the hightide of which stretched from, roughly, 1971 when the Bretton Woods agreement fell apart as the United States of America (USA) jettisoned the gold standard, to the global financial crisis and 'Great Recession' of 2007-8. A decade on, the spectre of stagnation lingers helping to stoke an anti-globalist nationalism with an extremist racist chorus. As if to celebrate a decade of stagnation, the world was then subjected to a once-in-a-hundred-year pandemic that threw the globally integrated economies into lockdown. As Western liberal capitalism struggles to recover legitimacy in the eyes of its citizens, other authoritarian varieties of capitalism prosper, most notably with the rise to economic and geo-political power of China.

The world populations expanded, reaching one billion by 1804 . With the rise of capitalism, material wealth and living standards began their rocky, uneven upward course. Industrialisation in Western Europe during the nineteenth century marked a distinct break in the millennial stagnation of the past, precisely at the time that the super-power of the Middle Ages, China, lost its material and scientific edge. Imperial expansion and competition between the major European powers changed the geo-political face of the Earth. Although, initially, the material benefits were tightly concentrated in the ruling classes of the imperial centre, and most of the negative impacts were borne by the masses in both the centre and periphery, eventually during the twentieth century, some of the benefits began to radiate out to workers and others in the lower classes and dependent economies. From 1950 onward a number of undeveloped countries experienced rapid 'catch-up' growth that has continued into the twenty-first century.

Of course, the past hundred years has also experienced two ruinous global wars, a conga line of minor wars, recurrent economic crises, and intractable environmental problems. In today's multi-polar world competing capitalisms threaten the very existence of our species and every other species on the planet. 
There is no current shortage of doomsayers, including those harking back to the ancient holy books. However, what is different and decidedly modern is the indisputable fact that collectively humanity has the technical knowledge and material basis for improving the lives of virtually everyone alive today and those generations to follow. Whether those potentialities can be realised is at least an open question. By refusing to consider how progress - in the sense of human survival and flourishing - might be achieved in concrete terms we are condemning humanity to the darkness of ages past.

This book is an attempt to keep open the quest, not as a reflex return to the simplistic forecasts of the Enlightenment but as a hard-headed exploration of the preconditions and paths of progress, in a conscious effort to disrupt the swing back of Machiavelli's pendulum. The basic premise of the book is that to do this requires resurrecting and supporting a strong consequentialist conception of social justice underpinning the strengthened rule of a substantially recast political democracy. Achieving this will require radical transformations in real-existing capitalism in its varietal forms and a bottom-up politics of renewal.

In what follows, the key dimension of real time is highlighted, along with a focus on path dependence in socio-economic and political developments. By 'real time' I mean time as actually experienced in social situations in which individuals have only a limited and incomplete awareness of its passage and the collective consequences of their actions temporally, as well as spatially, situated. This approach is to be distinguished from the 'dynamic' analyses of economists that typically treat time as an abstract construct in order to periodise their models without getting at the ontological nature of the implications of the second law of thermodynamics and the one-way, irreversible 'arrow of time'. ${ }^{6}$ A consequence of this latter approach is that processes of feedback and disequilibrium trump conventional analyses based on the Marshallian/ Newtonian concept of equilibrium.

This book follows on from and develops further ideas first presented in my two earlier books: The Affluent Society Revisited (2013) and Morality and Power: On Ethics, Economics and Public Policy (2017). It seeks to

6 One of the earliest economists to raise this perspective was Georgescu-Roegen (1971) in his book The Entropy Law and the Economic Process. Subsequent developments in Ecological Economics have developed this approach further. The arrow of time is associated with the work of nineteenth-century Scottish physicists William Thompson (Lord Kelvin) and James Clerk Maxwell, who articulated the importance of the laws of Thermodynamics, and the centrality of Entropy to all physical processes in the natural world. Maxwell mischievously posited an imaginary 'demon' or 'daemon' who could counter the second law and wreak havoc on the long, disorderly march to extinction. (For an entertaining commentary along these lines, see Clegg, 2019.) 
uncover the main barriers to achieving greater social justice in real-existing twenty-first-century global capitalism. My main thesis is that to move towards a more just world, in the actual circumstances of justice that we face, the weaknesses and threats to liberal democracy must be overcome through reconstructing robust, resilient social democracies. By robust and resilient, I mean that the inherent tension between class-driven capitalism in its current global state and liberal democracy as we know it must be kept in check; that the inherent oligarchic trajectory of capitalism must be stymied through radical institutional change and continual monitoring. This is a continuing political project, calling for new modes of mobilisation and the 'ecological' emergence of new values and world views. The arrival of the Covid-19 pandemic offers a unique opportunity to think and act big.

The book is divided into two parts. Part I focuses on the challenge of developing an adequate theory of social justice. Chapter 1 argues that in today's fragmented and volatile world, seeking justice is a moral imperative if we are to exert any constraints on the forces of anarchy and decay, the enemy of practical social progress. Chapter 2 provides an extended critique of a recent contribution to justice theory by political philosopher Gerald Gaus (2016). His book The Tyranny of the Ideal: Justice in a Diverse Society, takes issue with theories of justice that seek to lay down, once and for all, ethically charged rules or principles that guarantee ideal outcomes. He argues that only in societies riven by competing conceptions of ideal justice can a workable conception emerge with some chance of actually realising more just social arrangements and outcomes. There is, I would claim, much of value in Gaus's approach. However, for reasons I articulate, I believe that he overstates the force of the formal models that he presents to support his arguments for what he terms a Popperian-style 'open society'.

I also take issue with two other major recent contributions to the debate on justice. In the book by Alan Thomas (2019), Republic of Equals: Predistribution and Property Owning Democracy, Thomas develops a hybrid model of justice by linking a version of liberal republicanism to his reading of John Rawls's justice as fairness thesis. Again, there is much with which I agree, in relation to his radical policy requirements to limit the capitalist default to oligarchy as the major impediment to a just society and the stability of democracy. But I disagree that to achieve this we need to posit and prove a set of justice principles, to whit those of John Rawls. Likewise, many of the proposals made by Thomas Piketty (2020) in his monumental new book, Capital and Ideology, are similar to the agenda set out in this book. However, he does not explicate a conception of justice legitimating or anchoring the policies advanced, other than a casual reference to Rawls's principles, which he then (rightly in my view) dismisses as irrelevant. His views on justice are implicit, assuming that addressing what he calls current 'regimes of inequality' will automatically result in a just world. 
He thus ignores Amartya Sen's (2009) critique of purely 'resourcist' theories of justice that focus on the relative capacities of socially situated people to turn resources into effective functionings relevant to flourishing.

Chapter 3 presents an alternative attempt to develop and apply justice theory to the world as it is, that is, in full cognisance of the social, economic and political cleavages of our post-2008 situation. I distinguish between two main variants of real-existing capitalism: Western and Authoritarian. All capitalist societies are authoritarian in the sense that a dominant class structure imposes differential constraints across social classes. But the nature and workings of the constraints, and the authoritative institutions enforcing them, differ according to whether or not the political system and ideological props of representative democracy prevail.

Part II situates these deliberations in the context of the current attacks on Western-style democracy. The underlying theme of this part might be: can democracy as we know it survive globalism as it is becoming? Chapter 4 tries to re-establish the credentials of political systems traditionally defined as democratic. It will be argued that the pursuit of greater social justice, as articulated in Part I, is most effectively pursued in societies that can be broadly defined as democratic. Chapter 5 concentrates on the current philosophical, economic, ideological and political developments that undermine such societies. As such, we deal with contemporary arguments about the threats to representative democracy posed by the growing reach of global corporations, the rise of national populist political movements, the growth of the secret or dark state, the pervasive reach of big data, and the resurgence of ideologies eulogising elitist - that is, anti-democratic regimes. In the latter context, the argument is pursued by focusing on the recent case put for epistocracy by the political philosopher Jason Brennan (2016) in his book, Against Democracy. This chapter stresses the path-dependent drive of capitalism towards economic inequality and socio-political polarisation as the dominant internal threat to democracy. The chapter concludes by addressing the three major current external (external to the logic of capitalism, that is) existential threats to democracy and humanity in general: namely, climate change, nuclear weapons and viral pandemics. In Chapter 6, I offer an ecological approach to moving towards greater justice on the ground, fleshing out the 'comprehensive consequentialist' position articulated in my earlier book (Berry, 2017, chapters 9, 11 and 18). By 'ecological' I mean a step-wise approach to progressive, mutually reinforcing reductions in actually-existing injustice, brought about by recognising and utilising the interactions of diverse views, interest and resources in full comprehension of the 'circumstances of justice' that actually prevail and are likely (though not guaranteed) to continue to do so into the unforeseeable future.

As will become apparent through the text, this points to a particular social ontology, a definite understanding of what society is and the implications of 
what is has for what can be. It remains an open question as to whether democracy as we know it can be saved but my position is that for justice to prevail, we must try to shore up its foundations and superstructure as best we can.

Both parts of the book follow the same basic structure. The first chapters in each part ( 1 and 4$)$ focus on the why - why does it matter? The middle chapters (2 and 5) develop the key theoretical arguments. The last chapters ( 3 and 6) attempt to pull together and chart a way forward, to outline how progress towards greater justice in a robust democratic political society might work out. I argue that justice and democracy are necessarily linked once we understand the significance and 'bite' of the 'ontology of time'; chronic uncertainty casts a veil over the future, from behind which we need to make the 'best' choices, individually and collectively. There are no guarantees that the best choices turn out well. The two parts of the book are homologous. They are also mutually conditional; it is not, I suggest, possible to have one without the other, to enjoy justice without democracy and sustain democracy without justice.

Final comments gaze beyond the veil of the future to see if we can discern any identifiable landmarks that would increase our chances in this quest, or at least might provide some hope of steering in a sustainable direction.

It will become obvious that I have relied on a plethora of contributions to the topics covered in this book, and I acknowledge the key ones throughout. In order to keep the narrative flowing and focused on the arguments I wish to develop I have tried to confine subsidiary points and selective references to the copious literature to footnotes. The quotes in the main text are included in order to both acknowledge and express my interpretation of their contributions. I would like to acknowledge the helpful suggestions of three anonymous referees and the publishing experts at Edward Elgar Publishing, particularly Alex Pettifer and Harry Fabian, who encouraged me to develop my thoughts into the current book. I'm grateful to my editors at Elgar, Beatrice McCartney and Hetty Mosforth, for their help in getting the book to the reader. I have benefitted over the years discussing important matters of social theory and public policy with many colleagues and friends, in particular, Manfred Steger and Julie Lawson. I am grateful to my RMIT University colleague Chanel Koeleman for drafting the figures in Chapter 2.

This book is dedicated to my children, Anna, Jon and Lucy. 